\title{
OXISOL (FERRALSOL) DEVELOPMENT IN TWO AGRO-ECOLOGICAL ZONES OF GHANA: A PRELIMINARY EVALUATION OF SOME PROFILES
}

\author{
O. Dwomo ${ }^{I}$ and C.D. Dedzoe ${ }^{I}$ \\ ${ }^{I}$ CSIR - Soil Research Institute, Academy Post Office, Kwadaso-Kumasi, Ghana.
}

\begin{abstract}
Oxisoils (or Ferralsols) have been recognized in the High Rain Forest (HRF) agro-ecological zone of Ghana. There is no documented information about these soils in the Moist SemiDeciduous Forest (MSDF) agro-ecological zone of Ghana where climatic conditions conducive for Oxisol formation have been identified in parts of the zone. The paper seeks to establish the development of Oxisols or Ferralsols in parts of the MSDF so that appropriate management practices can be adopted for their sustainable use in the zone. Nine soil profiles were dug, described and sampled along a transect running from the HRF to MSDF zones of Ghana. Four of the profiles were located in the HRF and five in the MSDF. The HRF soils are Ninisu, Ankasa, Boi and Bremang series, while Wacri, Kukurantumi, Bekwai, Nzima and Kokofu series are the MSDF soils. Using rainfall and evapotranspiration data, morphological and easily measurable physico-chemical properties in the laboratory, the soils were evaluated for the development of Oxisols in the two agro-ecological zones in Ghana. These properties were also used to classify the soils into the Soil Taxonomy, world Reference Base for Soil Resources (WRB) and the Ghana Soil Classification Systems. Rainfall is higher in the HRF than MSDF. However, evapotranspiration distribution is similar in the two zones. Munsell hue is less variable in the HRF than the MSDF. This indicates greater moisture variability in the MSDF compared to the HRF. All the soils in the HRF and two in the MSDF (Wacri and Kukurantumi series) show pseudosand structure in the subsoil, which is characteristic with Oxisols (or Ferralsols). Though the soils are highly weathered with ECEC values being $<12 \mathrm{cmol}(+) / \mathrm{kg}$ soil, the intensity is greater with the HRF soils. Silt:clay ratios are $<0.7$ in the subsoils of the HRF soils compared to those of the MSDF. CEC:clay are mostly $<0.3$ in all the soils, indicating kaolinitic clay mineralogy. Under the Soil Taxonomy system, all the HRF soils and two in the MSDF (Wacri and Kukurantumi series) are Oxisols. The remaining three MSDF soils are Ultisols. The Oxisols classify as Ferralsols and the Ultisols, Acrisols in the WRB. This preliminary assessment shows that Oxisosl (or Ferralsols) also occur in the MSDF under udic moisture regimes. This is important for soil management in the MSDF.
\end{abstract}

Keywords: Oxisols, Ferralsols; agro-ecological zone; weathering intensity; pseudosand. 


\section{INTRODUCTION}

Globally, oxisols (or ferralsols) occupy about 9.8 million hectares which is equivalent to $7.5 \%$ of the global and $25 \%$ of the tropical land area. More than $95 \%$ of oxisols can be found in the tropics. The key factors considered to be responsible for the formation of oxisols are the age of the soils which has resulted from their occurrence on very old geomorphic surfaces and high degree of weathering (Beinroth et aI., 1974; Sanchez and Buol, 1974, Sanchez, 1976; Lepsh et al., 1977, van Wambeke et al., 1983). They can also develop in recently deposited pre -weathered sediments that originate from old regoliths (Eswaran and Tavernier, 1980; Batjes, 1996). In fact, geomorphic evolution of the landscape is considered an important factor in the formation of oxisols more than the kinds of soil. Daniels et al. (1971) have observed that oxisol development is controlled by the interaction of geomorphic, formative factors, rates and degrees of expression of pedogenic processes. Oxisols are also in the group of acid soils, and occur under udic, perudic and ustic moisture regimes (von Uexkull and Mutert, 1995; soil Survey Staff, 1998). According to Beinroth et al. (2000), the bulk of oxisols can be found in south America with most occurring in Brazil while the "Democratic Republic of Congo has the largest in Africa.

Beinroth et al. (2000) stated that oxisols are the most extensive soil group in the humid tropical forest ecosystem. They also consist of very large pool of sequestered carbon and special ecological niches of significant biological diversity. Von Uexkull and Mutert (1995) observed that the natural vegetation on these soils is an important factor for a stable global climate and the ultimate well-being of the human race particularly in terms of being a resource for food, timber, medicine and other products for humankind. These soils form a major land resource base for mankind and one of the few remaining frontiers for agricultural development, especially in Africa and South America.

The development, characteristics and classifica- tion of Ghanaian soils are significantly influenced by local climate and vegetation (Obeng, 1987) and this is observed in the tremendous differences among the soils in the country. The soils in the forest zone of the country differ from those in other parts by having a much thicker surface horizon due to high organic matter accumulation resulting from abundant leaf fall under the forest vegetation. The forest zone, which occupies an area of approximately 73,000 square kilometers, consists of the High Rainfall Forest (HRF) and the Moist SemiDeciduous Forest (MSDF) which are two important agro-ecological zones in the country, particularly, in terms of agricultural production. The dominant soils in the HRF are Oxisols (Ferralsols), Ultisols (Acrisols), Aquents and Aquepts (Gleysols), while in the MSDF they are Alfisols (Lixisols and Luvisols), Ultisols, Plinthaqualfs and Plinthaquults (Plinthosols), Inceptisols (Cambisols), and Aquents and Aquepts (Obeng 1987; Asiamah, 1987).

In Ghana, the climatic conditions especially udic moisture regimes in the HRF, in particular, and other areas in the MSDF favour the development of oxisols. Oxisols have been identified in the HRF where they develop over a variety of parent materials such as unconsolidated Tertiary deposits, peneplain drifts on high level erosion surfaces, Tarkwaian quartzites and pyritiferous phyllites in the Lower Birimian formations (Brammer, 1962). Charter (1958) used a synonymous term oxysols to classify them in the Interim Ghana Soil Classification System. However, their development in the MSDF has not been reported. As a result, they are considered as either Ultisols (Acrisols) or Alfisols (Luvisols and Lixisols) and managed as such.

The objective of this paper is to establish the occurrence of Oxisols or Ferralsols in the Moist Semi-Deciduous Forest (MSDF). The objective is achieved by examining some climatic conditions, especially rainfall, analyzing some key easily measurable soil properties with respect to Oxisol or Ferralsol development and then com- 
paring these with those in the HRF where these have already been established. This will assist in the adoption of appropriate management practices for the sustainable use of these soils in the MSDF.

\section{Materials and Methods}

The study sites were located along a transect measuring 400 kilometers, and running northwards from south-west in a north-easterly direction from the High Rain Forest (HRF) to the Moist Semi-Deciduous Forest (MSDF) agroecological ones of Ghana (Figure 1) the HRF is at the extreme south-western section and the MSDF, the south-central section of the country. The latter zone occupies about $80 \%$ of the entire forest zone of Ghana. A synoptic station in each zone (Axim in the HRF and Tafo in the MSDF) was examined to determine the mean monthly rainfall distribution and mean annual ranges together with evapotranspiration for a 35 -year period (from 1961-1995).

The soils examined in the two zones are developed from granites and Lower Birimian phyllites. However, the granites are different - they are biotite granites in the HRF and hornblende granites in the MSDF but both are of preCambrian age (Junner, 1940; Bates, 1962). The Lower Birimian phyllites are metamorphosed clay sediment of pre-Cambian age. Nine soil profiles (four in HRF and five in MSDF) were dug to depths ranging from $1.50-2.00 \mathrm{~m}$. In each zone and geology, the soils were examined in a catenary sequence. In the HRF, the catenas examined were Ninisu-Ankasa (developed over granite) and Boi-Bremang (developed over lower Birimian phyllites). Ninisu, Ankasa and Boi series are upland soil occurring on summits, upper and middle slopes, while Bremang series occurs on lower slopes. These catenas can be found in the Lower Tano drainage basin within the HRF (Ahn, 1961). In the MSDF, the catenas were WacriKukurantumi (both developed over hornblende granite) and Bekwai-Nzima-Kokofu (all developed over lower Birimian phyllites). Apart from Kokofu series, which is a lower slope soil, the rest are upland soils. In the study area of the MSDF we used, the two catenas can be found in the Ayensu/Densu drainage basin (Adu and Asiamah, 1992). The latter also occurred in the Kumasi Region and Birim drainage basin.

Soil selection for the study was based on geology and soil moisture regimes, which are phyllites, granites and udic moisture regimes. Van Wambeke (1992) established udic moisture regimes in the south-western part of Ghana (where the HRF is located) and some parts (e.g. Bunso, Kade and Tafo) in the Eastern Region of Ghana (which is part of the MSDF). Moisture regime, in particular, is an important factor in Oxisol development. Besides, the two groups of soils are very important in the zones in terms of land use. They are used for cocoa, Ghana's number one foreign exchange earner, rubber and oil palm (an important crop in the manufacturing industry, particularly soap and pharmaceuticals).

Each profile was described fully according to the Guidelines for soil Description (FAO < 1990). The profiles were sampled according to genetic horizons for the following physicochemical analyses: particle size distribution determined on particles $<2 \mathrm{~mm}$ in diameter by the hydrometer method (Bouyoucous, 1962); soil reaction (1:1 soil-water ratio) (Mclean, 1982); organic carbon determined by wet combustion method of Walkley and Black (Nelson and Sommers, 1982); total nitrogen by Kjeldahl digestion and distillation (Bremner, 1965); exchangeable bases determined in neutral ammonium acetate leachate (Thomas, 1982); exchangeable acidity by titration in $1.0 \mathrm{M}$ potassium chloride extract and effective cation exchange capacity (ECEC) by the summation of exchangeable acidity and exchangeable bases. Available phosphorus and available potassium were determined colorimetrically and by flame photometry respectively after extraction with Bray's P1 solution (Bray and Kurtz, 1945; Carson, 1975). The physico-chemical data were used in classifying the soils into the World Ref- 
erence Base for Soil Resources (1998) and Soil Taxonomy (Soil Survey Staff, 1999). From the analytical data, two parameters - silt:clay ratio and ECEC - were used to determine the weathering intensity of the soils in the two zone. In the case of the latter parameter, the relation ECEC x 100/\% clay [Van Wambeke (1967) and Westin (1969)].

The ECEC values were corrected for organic matter (OM) on the assumption that $1 \% \mathrm{OM}$ contributes $2 \mathrm{cmol}$ to the overall (Brady and
Weil, 1996). The physico-chemical data and the weathering intensity values obtained for the soil in the MSDF were compared with those of the HRF, where Oxisols have already been identified by Ahn (1964). The relation CEC clay content was used to determine the clay mineralogy of the soils based on the criteria of Soil survey Staff (1995).

\section{RESULTS AND DISCUSSION \\ Rainfall and evapotranspiration distribution in the two zones}

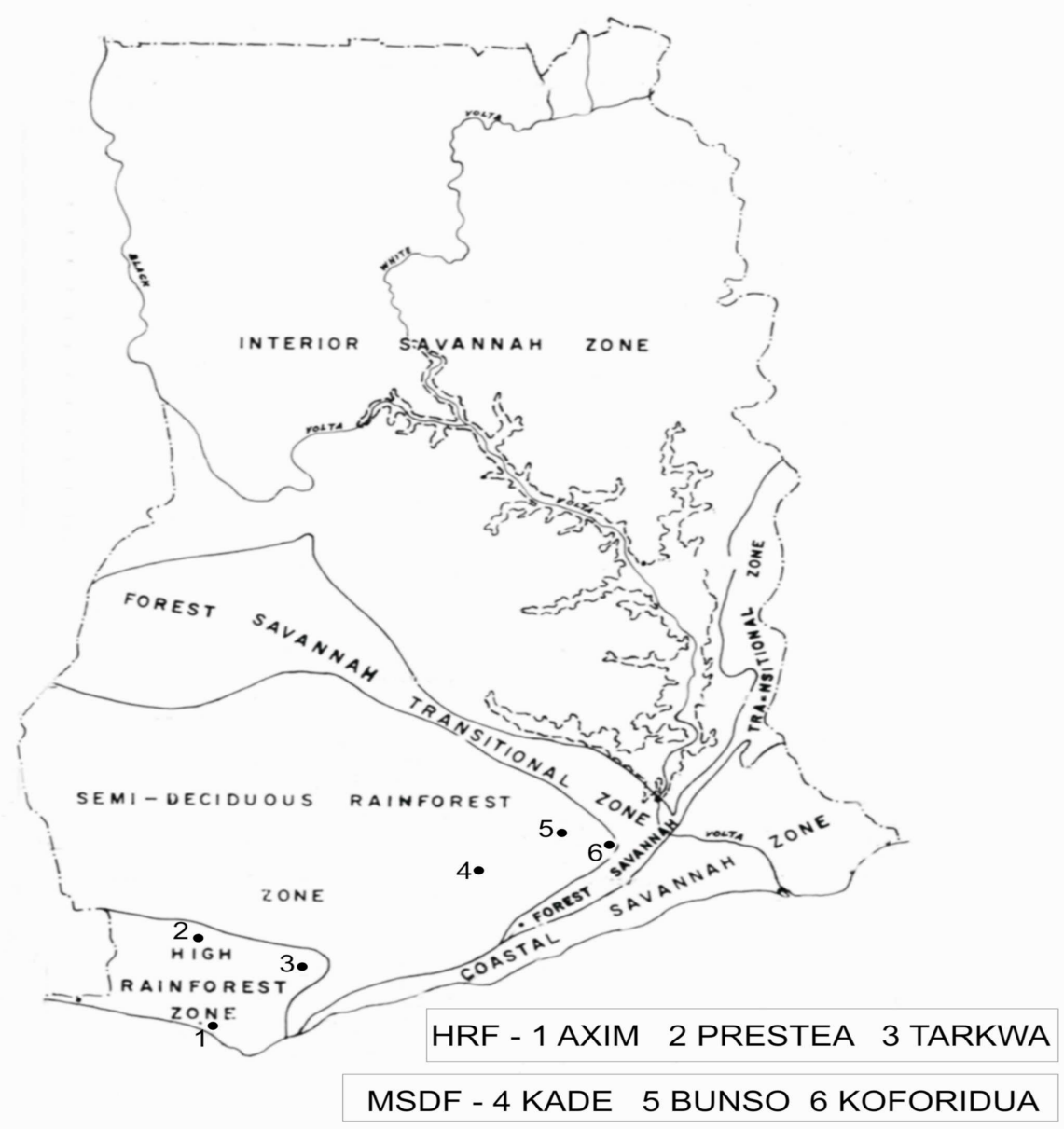

Figure 1: Location of sampling sites in the HRF and MSDF 
Rainfall is bimodal in the two zones (figure 2). The mean rainfall in the HRF is $>2000 \mathrm{~mm}$ while in the MSDF it is around $1700 \mathrm{~mm}$. In the two zones, the highest mean monthly amounts are recorded in June. The lowest rainfall amounts occur in January and February in the HRF but in December and January within the MSDF. Monthly evapotranspiration distribution is more or less the same in the two zones (Figure 2). Evapotranspiration exceeds rainfall in the dry months of November to March in the MSDF. These observed differences in evapotranspiration and rainfall throughout the year are necessary for the development of Oxisols (or Ferralsols) (van Wambeke, 1992). Where rainfall exceeds evapotranspiration in the year, as observed between the months of April and August (HRF) and May to August (MSDF), excess water percolates through the solum (Miller, 1983) and encourages leaching of soluble products resulting from weathering (van Wambeke et al., 1983).

Landscape, morphological and physical characteristics of the soils

Topography in the two zones is generally gently rolling (10-15\%). However, steeply dissected $(>30 \%)$ areas can also be found in the HRF. Above the general level of gently rolling topography, flat summits occur giving an indication of ancient peneplain residuals (Brash, 1962). In the two zones, particularly areas occupied by Birimian rocks, low-lying and flat areas can be found. These are the result of weathering which penetrates deeply into the rock mass, especially in the HRF. Throughout the HRF and MSDF, river terraces can be found at variable heights which range from 7 $36 \mathrm{~m}$ above local base level (Brash, 1962).

Landscape evolution in the two zones is mainly the result of erosion. A balance is achieved

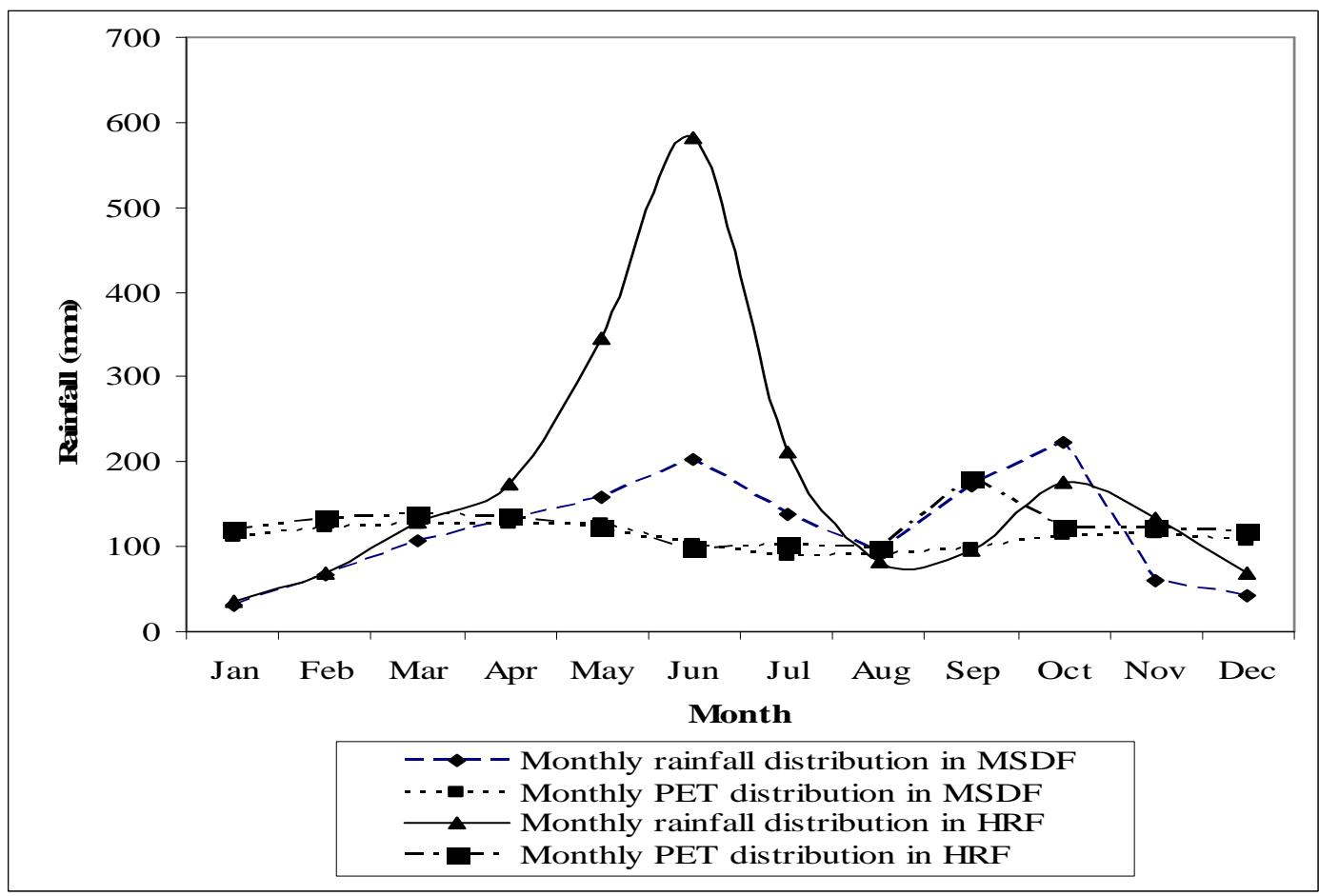

Figure 2: Monthly rainfall evapotranspiration distribution in the MSDF \& HRF 
between weathering, erosion and deposition. The process of erosion is slowed down by the vegetative cover in the two, but more in the HRF. Removal of the vegetation, as seen now, accelerates the erosion process. These processes of weathering and erosion result in the degradation of the uplands with a corresponding accumulation of materials in the lowlands, thus resulting in leveling of the topography.

Munsell hue is less variable in the HRF soils than those in the MSDF (Tables 1a and 1b). The dominant topsoil hues in the uplands of the HRF are 5YR and 7.5YR, while the subsoils have $2.5 \mathrm{YR}$ and $5 \mathrm{YR}$ with soil colours ranging from strong brown to yellowish red and red. The lower slope soils (Bremang series) have 10YR as the dominant hue with the colour being yellowish brown (Table 1a). The hues are similar for Wacri and Kukurantumi series studied in the MSDF. With the rest of the soils (Bekwai and Nsima series), hues are 10YR, 7.5YR, 5YR and 2.5YR (Table 1b). Schaefer et al., (2002) observed similar hues for some Brazilian upland Oxisols developed on the Diamantina Plateau found on the uplands of Minas Gerais State. The colours for the upland soils indicate well-drained conditions, while the lower slope soils show imperfectly drained conditions. All the soils in the HRF and two in the MSDF (Wacri and Kukurantumi series) show pseudosand structure in parts of the subsoil. This is a structure developed in an oxic (or ferralic) horizon and characterized by strong microaggregation and friable consistence (WRB, 1998). However, the dominant structure in the HRF and MSDF soils is weak to moderate, fine and medium subangular blocky. Another special feature of these soils is the presence of iron and manganese concretions in the subsoils (Table 1a and 1b).

Particle size distribution shows that while sand and silt content decreases with depth, clay content increases in the profiles examined within the two zones (Tables $2 \mathrm{a}$ and 2b). Depth distribution of clay shows that there is no clear clay accumulation in the Boi and Bremang profiles developed from Lower Birimian phyllites (Figure 3a) in the HRF. Though the clay increase is slight in these profiles, the increase does not meet the requirements of argillic (or argic B) horizon (Soil Survey Staff, 1999; WRB, 1998) bur rather on oxic horizon,. However, the granitic profiles (Ninisu and Ankasa) show clay accumulation (figure $3 b$ ). It can be deduced that in the HRF, soils developed from biotite granite have argillic horizon, while it is absent in those developed from lower Birimian phyllite under the same udic moisture regime.

The reverse is the case in the profiles in the MSDF. The profiles developed from hornblende granite (Wacri and Kukurantumi series) have no argillic horizon (figure 4a) whereas the three profiles developed from phyllite in the zone (Bekwai, Nzima and Kokofu series) have argillic horizons (Figure 4b). The presence of argillic horizons in these profiles indicates that they are not Oxisols. This also indicates that irrespective of geology, climate or rainfall has a significant influence on the formation of Oxisols in the two zones. Besides, the clay accumulation in these profiles which occur in a catenary sequence, decreases from summit to lower slope as drainage conditions change from well to imperfect.

This reduction in clay accumulation along the catena, gives an indication of progressive clay destruction (Lucas et al., 1984; Andrade et al., 1997).

Brinkman (1979) attributed this destruction to ferrolysis which occurs under wet climatic conditions as observed in the two zones, particularly the HRF.. The observed differences in clay accumulation among the soils developed from the two geologies can be attributed to the following:

*Udic moisture conditions exist in some parts of the MSDF where Wacri and Kukurantumi series occur. 
*The phyllite soils in the MSDF occur under ustic moisture regime. Under these two moisture regimes, weathering and leaching proceed faster under udic than ustic conditions

*The more basic a mineral the less stable it is (Barshad, 1965).

These differences in relative stability of the two minerals may have accounted for the observed variation in clay distribution with depth in the granitic soils in the two zones. Chadwick and Graham (2000) also attributed such differences to processes occurring in soils depending on soil-landscape position and different climatic conditions as observed.

The silt-clay rations (Table 3 and 4) of the profiles in the two zones show that most of the soils in HRF have values below 0.7 within the subsoil and similar to those observed by Schaefer et al. (2002) but higher than those observed for some Puerto Rican Oxisols (Beinroth, 1982). The weathering intensity is, however, greater in the HRF, which has a higher rainfall amount than the MSDF. CEC:clay ratios show that clay mineralogy of the soils is mostly kaolinite. This further shows that soils are highly weathered.

\section{Chemical characteristics of the soils}

The soils in the HRF are extremely acidic with $\mathrm{pH}$ values generally $<4.0$ throughout the profiles (Table 2a). However, in the MSDF, pH values range from 4.0-5.4 in the B-horizon. These low $\mathrm{pH}$ values are conducive for the process of ferrallitization or desilication, which leads to the formation of oxisols (or ferralsols).

Table: 1a Morphological characteristics of selected soils in the HRF

\begin{tabular}{|c|c|c|c|c|c|c|c|}
\hline $\begin{array}{l}\text { Soil } \\
\text { Series }\end{array}$ & $\begin{array}{l}\text { Horizon } \\
\text { Symbol }\end{array}$ & $\begin{array}{l}\text { Depth } \\
\text { (cm) }\end{array}$ & $\begin{array}{l}\text { Colour } \\
\text { (moist) }\end{array}$ & Structure & nsistence & Texture & Special features \\
\hline \multirow[t]{5}{*}{ Ninisu } & $\mathrm{Ah}$ & $0-6$ & 5YR 3/2 & wk-fn-med-gr & friable & SL & \multirow{5}{*}{$\begin{array}{l}\text { pseudosand structure } \\
\text { pseudosandstructure; cmfinqg } \\
\text { cfngq; mhFe/Mg conc. } \\
\text { cfnqg; fn distinct mottles }\end{array}$} \\
\hline & BA & $6-20$ & 5YR 5/6 & wk-med-sab & friable & SCL & \\
\hline & Btcl & $20-60$ & 5YR 5/8 & wk-fn-med-sab & friable & $\mathrm{C}$ & \\
\hline & Btc2 & $60-105$ & 2.5YR 5/6 & mo-med-co-sab & firm & $\mathrm{C}$ & \\
\hline & Btcv & $105-150$ & $2.5 \mathrm{YR} 5 / 6$ & mo-med-co-sab & firm & $\mathrm{C}$ & \\
\hline \multirow[t]{6}{*}{ Ankasa } & Ah1 & $0-5$ & $5 Y R 3 / 2$ & mo-fn-med.gr & friable & SL & \multirow{6}{*}{$\begin{array}{l}\text { pseudosand structure } \\
\text { pseudosand structure } \\
\text { pseudosandstructure; abfnqg } \\
\text { common fine quartz gravel }\end{array}$} \\
\hline & Ah2 & $5-12$ & 7.5YR 3/2 & mo-fn-med-sab & friable & SCL & \\
\hline & BA & $12-36$ & 7.5YR 4/4 & mo-fn-med-sab & friable & SCL & \\
\hline & Bts1 & $36-72$ & 5YR 5/8 & wk-med-co-sab & firm & $\mathrm{C}$ & \\
\hline & Bts2 & $72-110$ & $2.5 \mathrm{YR} 5 / 6$ & wk-med-co-sab & firm & $\mathrm{C}$ & \\
\hline & $\mathrm{Bt}$ & $110-150$ & $2.5 \mathrm{YR} 5 / 6$ & wk-med-co-sab & firm & $\mathrm{C}$ & \\
\hline \multirow[t]{5}{*}{ Boi } & $\mathrm{Ah}$ & $0-8$ & 7.5YR 4/3 & mo-fn-med-gr & friable & $\mathrm{L}$ & \multirow{5}{*}{$\begin{array}{l}\text { pseudosand structure } \\
\text { pseudosandstructure; cmfnqg } \\
\text { cfnqg;absFe/Mg conc./stones } \\
\text { cfnqg;absFe/Mg.conc./stones }\end{array}$} \\
\hline & BA & $8-20$ & 7.5YR 4/4 & wk-mo-med-sab & friable & $\mathrm{L}$ & \\
\hline & Btcs & $20-75$ & 5YR 5/6 & wk-mo-med-sab & friable & $\mathrm{C}$ & \\
\hline & Btv1 & $75-130$ & 5YR 5/6 & wk-mo-med-sab & firm & $\mathrm{C}$ & \\
\hline & $2 \mathrm{Btv} 2$ & $130-150$ & 5YR 5/6 & wk-fn-med-sab & firm & $\mathrm{C}$ & \\
\hline \multirow[t]{6}{*}{ Bremang } & Ap & $0-6$ & $10 \mathrm{YR} 3 / 2$ & mo-med-gr & friable & CL & \multirow{6}{*}{$\begin{array}{l}\text { pseudosand structure } \\
\text { pseudosand structure } \\
\text { pseudosand structure } \\
\text { cfnmed distinct mottles } \\
\text { ab coarse and distinct mottles }\end{array}$} \\
\hline & BA & $6-20$ & 10YR 4/4 & mo-med-sab & friable & CL & \\
\hline & Bt1 & $20-60$ & 10YR 5/6 & mo-med-sab & friable & CL & \\
\hline & Bt2 & $60-110$ & $10 Y R$ 5/6 & mo-med-sab & firm & $\mathrm{C}$ & \\
\hline & Btv1 & $110-135$ & 10YR 5/6 & mo-med-co-sab & firm & $\mathrm{C}$ & \\
\hline & Btv2 & $135-150$ & 10YR 5/6 & mo-med-c0-sab & firm & $\mathrm{C}$ & \\
\hline
\end{tabular}

C - common; $\mathrm{m}$ - many; fn - fine; $\mathrm{q}$ - quartz; gravel; Fe/Mg conc. - iron and manganese concretions; $\mathrm{ab}$ - abundant; $\mathrm{s}$ - soft; $\mathrm{h}$ hard; wk - weak; mo - moderate; med - medium; co - course; gr - gramular; sab - subangular blocky; L - loam; SL - sandy loam; $\mathrm{SCL}$ - sandy clay loam; CL - clay loam; C - clay 
Table: $1 \mathrm{~b}$ Morphological characteristics of the soils of the MSDF

\begin{tabular}{|c|c|c|c|c|c|c|c|}
\hline $\begin{array}{l}\text { Soil } \\
\text { series }\end{array}$ & $\begin{array}{l}\text { Horizon } \\
\text { Symbol }\end{array}$ & $\begin{array}{l}\text { Depth } \\
(\mathrm{cm})\end{array}$ & $\begin{array}{l}\text { Colour } \\
\quad(\text { moist })\end{array}$ & Structure & Consistence & Texture & Special features \\
\hline \multirow[t]{5}{*}{ Wacri } & Ap & $0-8$ & 7.5YR 4/2 & wk-med-gr & friable & SL & \multirow{5}{*}{$\begin{array}{l}\text { pseudosandstructure; cqfnqg } \\
\text { pseudosand structure, fwfnqg } \\
\text { pseudosandstructure;csFe/Mg }\end{array}$} \\
\hline & $\mathrm{BA}$ & $8-30$ & $5 \mathrm{YR} 4 / 6$ & wk-med-sab & friable & SCL & \\
\hline & $\mathrm{E}$ & $30-57$ & $5 Y R$ 4/6 & wk-med-sab & firm & CL p & \\
\hline & Btcs & $57-97$ & $2.5 \mathrm{YR} 4 / 6$ & wk-med-sab & firm & $\mathrm{SC}$ & \\
\hline & Btv & $97-150$ & $2.5 \mathrm{YR} 4 / 6$ & wk-med-sab & firm & $\mathrm{C}$ & \\
\hline \multicolumn{2}{|c|}{ Kukurantumi Ap } & $0-8$ & 7.5YR 3/2 & wk-fn-gr & friable & SL & \multirow{5}{*}{$\begin{array}{l}\text { pseudosand structure; fwfnqgst } \\
\text { pseudosandstructure;fwfnqg } \\
\text { pseudosand structure; trdegr }\end{array}$} \\
\hline & $\mathrm{AB}$ & $8-28$ & 7.5YR 4/3 & wk-fn-gr & friable & SL & \\
\hline & $\mathrm{E}$ & $28-65$ & 7.5YR 4/4 & wk-med-sab & friable & SCL & \\
\hline & $\mathrm{Bt}$ & $65-104$ & 7.5YR 4/4 & wk-meb-sab & firm & SCL & \\
\hline & $\mathrm{CB}$ & $104-150$ & 7.5YR 5/8 & mo-med-sab & firm & $\mathrm{SC}$ & \\
\hline \multirow[t]{6}{*}{ Bekwai } & $\mathrm{Ah}$ & $0-9$ & $10 \mathrm{YR} 3 / 3$ & wk-fn-gr & friable & $\mathrm{L}$ & \multirow{6}{*}{$\begin{array}{l}\text { fw quartz gravel/stones;mhFe } \\
\text { common quartz gravel; chFe } \\
\text { common hard Fe concretions } \\
\text { common hard Fe concretions }\end{array}$} \\
\hline & $\mathrm{BA}$ & $9-17$ & 7.5YR 4/6 & wk-fn-sab & friable & $\mathrm{L}$ & \\
\hline & Btcs & $17-30$ & $5 Y R$ 4/6 & wk-fn-sab & friable & $\mathrm{CL}$ & \\
\hline & Btv1 & $30-61$ & $5 \mathrm{YR} 4 / 8$ & wk-fn-med-sc & sab firm & $\mathrm{C}$ & \\
\hline & $2 \mathrm{Btv}$ & $261-120$ & $2.5 \mathrm{YR} 4 / 8$ & mo-fn-med-sc & $\mathrm{sab}$ firm & $\mathrm{C}$ & \\
\hline & $2 \mathrm{Btv} 3$ & $120-150$ & 5YR 5/8 & mo-fn-med-s & sab firm & $\mathrm{C}$ & \\
\hline \multirow[t]{6}{*}{ Nzima } & Ap & $0-10$ & $10 Y R 3 / 3$ & wk-fn-gr & friable & SL & \multirow{6}{*}{$\begin{array}{l}\text { common hard } \mathrm{Fe} \text { concretions } \\
\text { common quartz gravel/stone } \\
\text { common hard Fe concretions } \\
\text { cmedqg;chFe/Mn;m red mottles } \\
\text { fw soft } \mathrm{Fe} / \mathrm{Mn} \text {;mdi red mottles }\end{array}$} \\
\hline & BA & $10-20$ & 10YR 4/6 & wk-fn-sab & friable & $\mathrm{L}$ & \\
\hline & Btcs & $120-40$ & 7.5YR 5/6 & mo-med-sab & firm & $\mathrm{CL}$ & \\
\hline & Btcs & $240-70$ & 7.5YR 5/8 & mo-med-sab & firm & $\mathrm{SiC}$ & \\
\hline & Btv1 & $70-105$ & $7.5 \mathrm{YR} 5 / 8$ & mo-med-sab & firm & CL & \\
\hline & Btv2 & $105-150$ & 010YR 5/6 & mo-med-co-s & sab firm & $\mathrm{CL}$ & \\
\hline \multirow[t]{6}{*}{ kokofu } & Ap & $0-7$ & $10 Y R 3 / 3$ & wk-med-gr & friable & SL & \multirow{6}{*}{$\begin{array}{l}\text { common hard } \mathrm{Fe} \text { concretions } \\
\text { common quartz gravel/stones } \\
\text { common hard Fe concretions } \\
\text { cmedqg;chFe/Mn;m red mottles } \\
\text { fw soft } \mathrm{Fe} / \mathrm{Mn} ; \mathrm{m} \text { red mottles }\end{array}$} \\
\hline & $\mathrm{BA}$ & $7-19$ & 10YR 4/6 & wk-med-sab & friable & $\mathrm{L}$ & \\
\hline & $\mathrm{E}$ & $19-40$ & 7.5 YR $5 / 6$ & mo-med-sab & firm & $\mathrm{CL}$ & \\
\hline & Btcs & $40-82$ & 7.5YR 5/8 & mo-med-sab & firm & $\mathrm{SiC}$ & \\
\hline & Btv1 & $82-106$ & 7.5YR 5/8 & mo-med-sab & firm & CL & \\
\hline & Btv2 & $106-150$ & $10 \mathrm{YR} 5 / 6$ & mo-med-co-s & sab firm & CL & \\
\hline
\end{tabular}

FW-few; c-common; m-many; fn-fine; q-quartz; gravel; Fe/Mg conc.-iron and manganese concretions; ab-abundant; s-soft; h-hard; st-stone; wk-weak; mo-moderate; med-medium; co-coarse; gr-granular; sab-subangular blocky; L-loam; SL-sandy loam;

SCL-sandy clay loam; CL-clay loam; C-clay; trdegr-traces of decomposing granite; di-distinct

Batjes (1995, 1996) observed similar pH patterns for Oxisols. These conditions are found in all the soils studied in the HRF and two (Wacri and Kukurantumi series) in the MSDF. At these low $\mathrm{pH}$ values, exchangeable bases are correspondingly very low throughout the profiles (Table 1 and 2). This indicates leaching of soluble bases out of the soil.

Organic carbon levels are higher in the topsoils of the HRF than the MSDF profiles. The levels range from high to very high (2.50-3.50\%).

This indicates a greater accumulation of organic matter in the surface horizons of the HRF, as a result of abundant leaf fall than in the soils of the MSDF. The subsoil levels are generally very low $(<0.6 \%)$. Exchangeable basic cation levels are generally lower in the HRF than the MSDF profiles, thus indicating greater leaching in the profiles of the former zone. 
Oxisol (Ferralsol) development in two agro-ecological zones of Ghana...

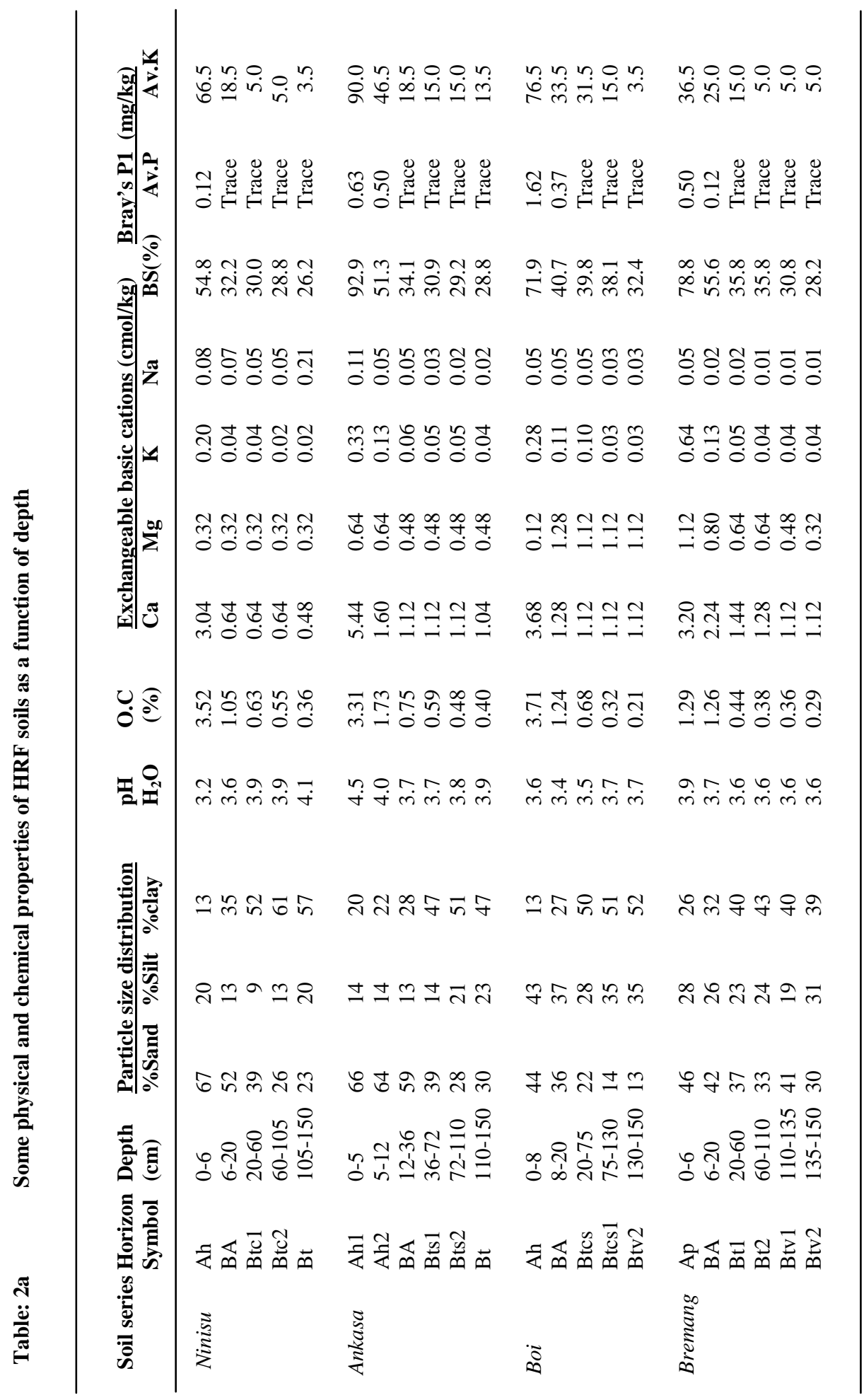

Journal of Science and Technology (C) KNUST August 2010 


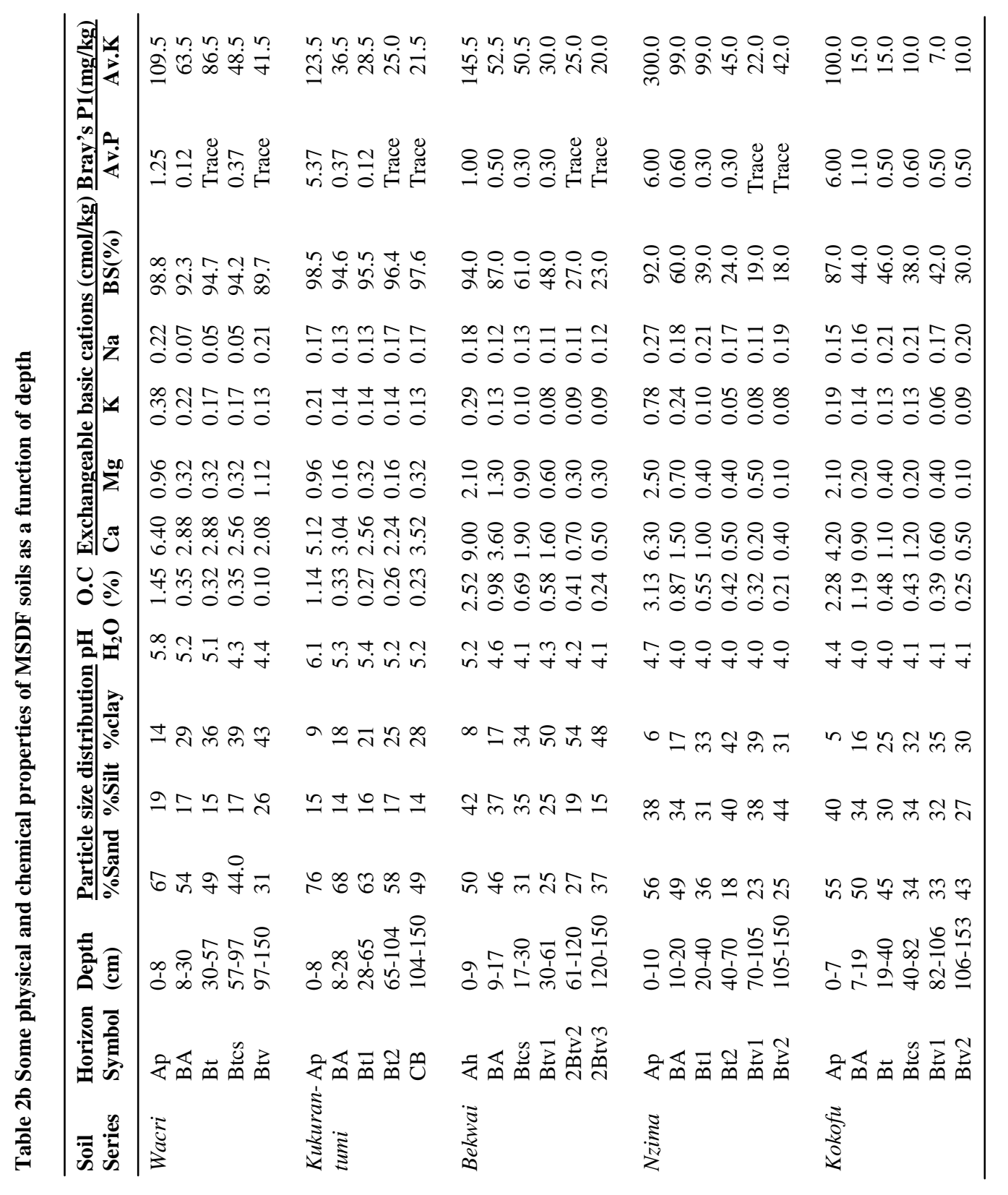


Oxisol (Ferralsol) development in two agro-ecological zones of Ghana...

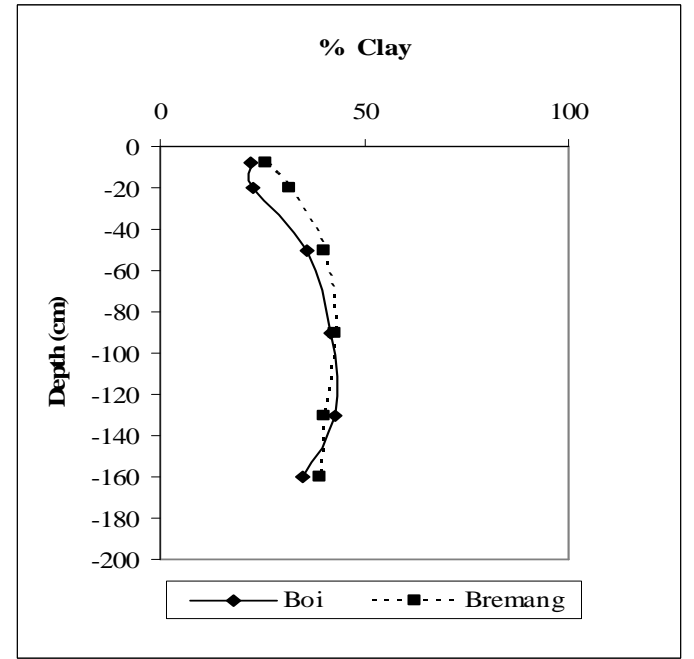

Figure 3a: Depth distribution of clay in phyllitic profiles of $\mathrm{HRF}$

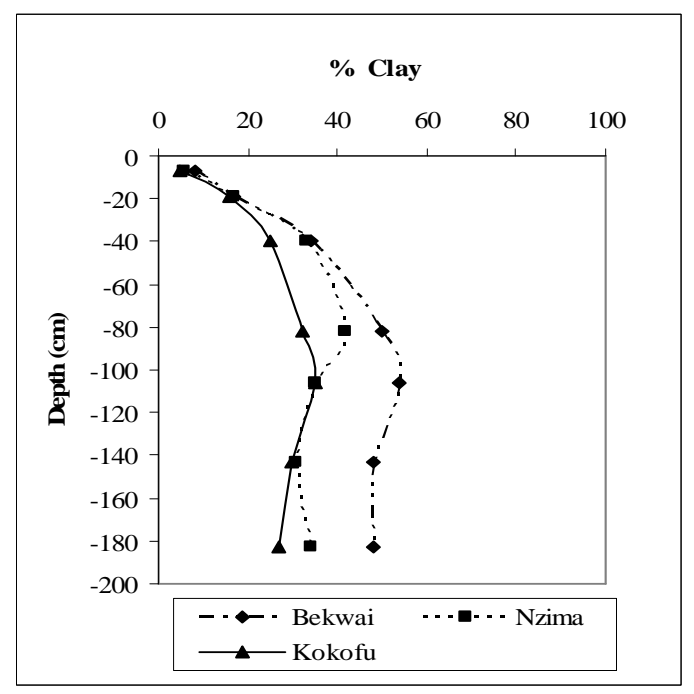

Figure 4a: Depth distribution of clay in phyllitic profiles of MSDF

Base saturation is $<50 \%$ in the subsoils of the HRF profiles and the soils developed over phyllite in the MSDF. This is a further reflection on the low base status of these soils. It is, however, very high $(>80 \%)$ in the two profiles developed over granite in the MSDF (Tables 1 and 2). Available $\mathrm{P}$ is very low ( $<3 \mathrm{mg} / \mathrm{kg}$ soil)

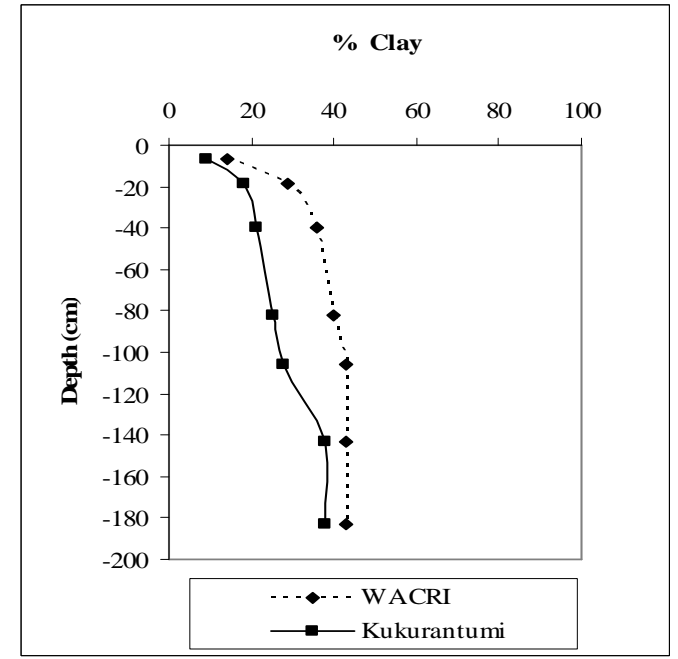

Figure 3b: Depth distribution of clay in granitic profiles of HRF

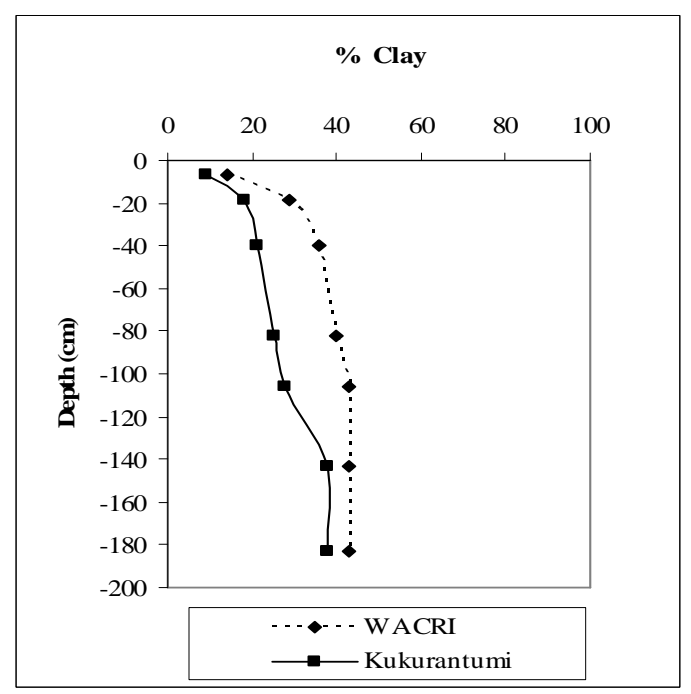

Figure 4b: Depth distribution of clay in granitic profiles of MSDF

and occurs in traces in most of the profiles examined in the two zones. These levels may be due to the low soil $\mathrm{pH}$ levels which normally result in $\mathrm{P}$ fixation, thus making it unavailable for plant uptake.

Available K levels are moderate $(50-100 \mathrm{mg} / \mathrm{kg}$ 
soil) in the topsoil of Ninisu, Ankasa and Boi profiles.

The levels are very low ( $<40 \mathrm{mg} / \mathrm{kg}$ soil) in the subsoil of these profiles and throughout the Bremang profile.

In the case of the MSDF profile, moderate to very high levels occur in the top $10 \mathrm{~cm}$ of all the profiles. Moderate levels occur within 10$40 \mathrm{~cm}$ of the Wacri, Bekwai and Nzima profiles. Very low levels occurred in a greater part of the Kokofu profile. These low nutrient levels show that the soils are intensely leached, particularly in the HRF.

Effective cation exchange capacity (ECEC) levels are very low ( $<5 \quad \mathrm{cmol}(+) / \mathrm{kg}$ soil $)$ throughout the profiles examined, especially in the B-horizons. Correcting for OM influence on the ECEC, weathering intensity values range from $4.2-5.4 \mathrm{cmol}(+) / \mathrm{kg}$ clay and $7.0-8.9 \mathrm{cmol}$ $(+) / \mathrm{kg}$ clay for the HRF and MSDF soils respectively. These values are below or less than $12 \mathrm{cmol}(+) / \mathrm{kg}$ clay, thus indicating very strongly weathered soils. Weathering intensity is, therefore, higher in the HRF than MSDF.

\section{Soil Classification}

The nine soils studied are placed in two international systems of classification (Table 5) currently used in Ghana and the Ghanaian Classification system (Brammer, 1962). The international systems are Soil Taxonomy (soil Survey Staff, 1998) and World Reference Base for Soil Resources (WRB) (1998). In the Soil Taxonomy, Oxisols and Ultisols, which are Ferralsols and Acrisol in the World Reference Base were identified. The criteria and rationale used in the classification are briefly discussed below:

Table 3:Some weathering intensity parameters and clay activity classes of profiles examined in the HRF

\begin{tabular}{|c|c|c|c|c|c|c|c|}
\hline \multicolumn{8}{|c|}{ Weathering intensity parameters } \\
\hline Soil Name & Horizon & $\begin{array}{l}\text { Depth } \\
\text { (cm) }\end{array}$ & ECEC & $\frac{\text { Corrected ECEC x } 100}{\% \text { Clay }}$ & Silt:Clay & CEC:Clay & $\begin{array}{l}\text { Clay activity } \\
\text { class }\end{array}$ \\
\hline Ninisu & $\mathrm{Ah}$ & $0-6$ & 6.64 & 8.40 & 1.60 & 0.50 & Mixed \\
\hline \multirow[t]{4}{*}{ Series } & BA & $6-20$ & 3.32 & 4.00 & 0.36 & 0.09 & Kaolinitic \\
\hline & Btcs1 & $20-60$ & 3.50 & 4.60 & 0.18 & 0.07 & “ \\
\hline & Btcs2 & $60-105$ & 3.58 & 4.20 & 0.21 & 0.06 & “ \\
\hline & $\mathrm{Bt}$ & $105-150$ & 3.93 & 5.40 & 0.35 & 0.07 & “ \\
\hline Ankasa & Ah1 & $0-5$ & 7.02 & 6.77 & 0.73 & 0.36 & Mixed \\
\hline \multirow[t]{5}{*}{ Series } & Ah2 & $5-12$ & 4.72 & 7.68 & 0.61 & 0.21 & Kaolinitic \\
\hline & BA & $12-36$ & 5.01 & 6.11 & 0.46 & 0.18 & “ \\
\hline & Btes & $136-72$ & 5.43 & 9.43 & 0.30 & 0.12 & “ \\
\hline & Btcs & $272-110$ & 5.72 & 9.55 & 0.36 & 0.10 & “ \\
\hline & $\mathrm{Bt}$ & $110-150$ & 5.48 & 10.17 & 0.49 & 0.12 & “ \\
\hline Boi & $\mathrm{Ah}$ & $0-8$ & 7.12 & 5.84 & 3.48 & 0.60 & Mixed \\
\hline \multirow[t]{4}{*}{ Series } & BA & $8-20$ & 4.72 & 9.70 & 1.24 & 0.17 & Kaolinitic \\
\hline & Btes & $20-75$ & 4.40 & 5.19 & 0.56 & 0.09 & “ \\
\hline & Btcs & $175-130$ & 4.36 & 7.30 & 0.68 & 0.08 & “ \\
\hline & Btcs2 & $130-150$ & 4.14 & 7.26 & 0.68 & 0.08 & “ \\
\hline Bremang & $\mathrm{Ah}$ & $0-6$ & 3.36 & 4.57 & 1.10 & 0.13 & Kaolinitic \\
\hline \multirow[t]{5}{*}{ Series } & BA & $6-20$ & 5.74 & 11.03 & 0.82 & 0.18 & “ \\
\hline & Bt1 & $20-60$ & 6.00 & 13.00 & 0.59 & 0.15 & “ \\
\hline & Bt2 & $60-110$ & 5.82 & 12.19 & 0.57 & 0.14 & “" \\
\hline & Btv1 & $110-135$ & 5.35 & 11.89 & 0.46 & 0.13 & “ \\
\hline & Btv2 & $135-150$ & 5.29 & 12.34 & 0.80 & 0.14 & “ \\
\hline
\end{tabular}


Oxisol (Ferralsol) development in two agro-ecological zones of Ghana...

Table 4: Some weathering intensity parameters and clay activity classes of profiles examined in the MSDF

\begin{tabular}{|c|c|c|c|c|c|c|c|}
\hline \multirow[b]{2}{*}{ Soil Name } & \multirow[b]{2}{*}{$\begin{array}{l}\text { Horizon } \\
\text { (cm) }\end{array}$} & \multirow[b]{2}{*}{ Depth } & \multicolumn{3}{|c|}{ Weathering intensity parameters } & \multirow[b]{2}{*}{ CEC:Clay } & \multirow[b]{2}{*}{$\begin{array}{l}\text { Clay activ- } \\
\text { ity class }\end{array}$} \\
\hline & & & ECEC & $\frac{\text { Corrected ECEC x } 100}{\% \text { Clay }}$ & Silt:Clay & & \\
\hline \multirow[t]{5}{*}{ Wacri } & $\mathrm{Ah}$ & $0-8$ & 8.06 & 39.71 & 1.30 & 0.60 & Mixed \\
\hline & BA & $68-30$ & 3.92 & 11.45 & 0.57 & 0.14 & Kaolinitic \\
\hline & Bt & $30-57$ & 3.75 & 8.87 & 0.42 & 0.11 & “ \\
\hline & Btcs & $57-97$ & 3.42 & 7.14 & 0.42 & 0.09 & “ \\
\hline & Btv & $97-150$ & 3.90 & 8.17 & 0.61 & 0.09 & “ \\
\hline \multirow[t]{5}{*}{$K^{\prime}$ tumi } & Ap & $0-8$ & 6.56 & 51.24 & 1.74 & 0.70 & Mixed \\
\hline & $\mathrm{BA}$ & $8-28$ & 3.67 & 17.06 & 0.79 & 0.20 & Kaolinitic \\
\hline & Bt1 & $8-65$ & 3.30 & 13.16 & 0.74 & 0.15 & " \\
\hline & Bt2 & $65-104$ & 2.80 & 9.20 & 0.68 & 0.11 & “ \\
\hline & $\mathrm{CB}$ & $104-150$ & 4.24 & 0.24 & 0.49 & 0.15 & “ \\
\hline \multirow[t]{6}{*}{ Bekwai } & $\mathrm{Ah}$ & $0-9$ & 12.37 & - & 5.25 & 1.50 & Vermiculite \\
\hline & BA & $9-17$ & 5.95 & 25.76 & 2.24 & 0.36 & Mixed \\
\hline & Btcs & $17-30$ & 5.05 & 11.32 & 1.01 & 0.15 & Kaolinitic \\
\hline & Btv1 & $30-61$ & 4.99 & 7.98 & 0.50 & 0.10 & “ \\
\hline & 2Btv2 & $61-120$ & 4.50 & 7.04 & 0.35 & 0.08 & “ \\
\hline & $2 \mathrm{Btv} 3$ & $120-150$ & 4.31 & 8.23 & 0.32 & 0.09 & “ \\
\hline \multirow[t]{6}{*}{ Nzima } & Ap & $0-10$ & 10.65 & 95.45 & 6.90 & 1.90 & Vermiculite \\
\hline & $\mathrm{BA}$ & $10-20$ & 4.37 & 17.39 & 2.10 & 0.26 & Kaolinitic \\
\hline & Btca1 & $20-40$ & 4.41 & 10.49 & 0.97 & 0.14 & “ \\
\hline & Btcs2 & $40-70$ & 4.67 & 9.57 & 0.98 & 0.11 & “ \\
\hline & Btv1 & $70-105$ & 4.64 & 11.13 & 1.12 & 0.13 & “ \\
\hline & Btv2 & $105-150$ & 4.32 & 12.65 & 1.42 & 0.14 & “ \\
\hline \multirow[t]{6}{*}{ Kokofu } & Ap & $0-7$ & 7.49 & 72.00 & 7.90 & 1.50 & Vermiculite \\
\hline & BA & $7-19$ & 3.15 & 6.60 & 2.13 & 0.20 & Kaolinitic \\
\hline & $\mathrm{Bt}$ & $19-40$ & 4.04 & 13.22 & 1.24 & 0.16 & “ \\
\hline & Btcs & $40-82$ & 4.54 & 12.00 & 1.06 & 0.14 & “ \\
\hline & Btv1 & $82-106$ & 4.18 & 10.10 & 0.93 & 0.12 & “ \\
\hline & Btv2 & $106-150$ & 3.84 & 11.47 & 0.88 & 0.13 & “" \\
\hline
\end{tabular}

\section{A. Soil Taxonomy}

\section{Oxisols}

The subsurface horizons of Ninisu, Ankasa, Boi, Bremang, Wacri and Kukurantumi series qualify for oxic horizons as defined by soil Survey Staff (1998). They are classified as Oxisols. They key out as Udox under the suborder level sice they occur under udic moisture regime. At the great group level, Ninisu, Ankasa and Boi series qualify as Kandiudox.

Bremang series qualifies as Hapludox. Wacri and Kukurantumi series key out as Eutrudox as base saturation by $\mathrm{NH}_{4} \mathrm{OAc}$ is greater than $35 \%$ throughout the two profiles. At the subgroup level, Ninisu, Ankasa and Boi series are Plinthic Kandiudox, while Bremang series is Plinthic Hapludox on account of the occurrence of plinthite within $125 \mathrm{~cm}$ of the soil surface. 
Wacri series is a Plinthic Eutrudox owing to the presence of plinthite within $125 \mathrm{~cm}$ of the soil surface. Kukurantumi series is a Typic Eutrudox.

2. Ultisols

Bekwai, Nzima and Kokofu series have argillic horizons with base saturation less than $35 \%$ within $125 \mathrm{~cm}$ of the soil surface. They therefore qualify as Ultisols. At the suborder level, they are Ustults as they occur under an ustic moisture regime. They key out as Plinthustults at the great group level in having plinthite within 150 $\mathrm{cm}$ of the mineral soil surface. They are all Typic Plinthustults at the subgroup level.

\section{B. World Reference Base (WRB)}

\section{Ferralsols}

Ninisu, Ankasa, Boi, Bremang (HRF profiles), Wacri and Kukurantumi series (MSDF profiles) key out as Ferralsols. They have pseudosand structure and are friable in the subsoil indicating ferralic horizon. All the HRF profiles were classified as Plinthic Ferralsols because they have plinthic horizons in the subsoil. With the MSDF profiles, Wacri series was classified as a Rhodi-Lixic Ferralsol. It had dark red colours with munsell hues of $5 \mathrm{YR}$ and $2.5 \mathrm{YR}$, low ECEC and high base saturation. Kukuran tumi series, on the other hand, was a Xanthic Ferralsol with a munsell hue of 7.5YR throughout the profile and a colour value, moist, of 4 or more.

\section{Acrisols}

Bekwai, Nzima and Kokofu series are Acrisols. They have an argic horizon, CEC < $24 \mathrm{cmol}(+) / \mathrm{kg}$ clay and a base saturation $<50 \%$ in some parts of the profile. They are Plinthic Acrisols as plinthite occurs in the subsoil. However, Bekwai and Nzima series are Ferri-Plinthic Acrisols by the occurrence of a ferric horizon characterized by iron concretions, thus distinguishing them from Kokofu series which is classified at this level as Gleyi-Plinthic Acrisol due to the presence of gleyic colour pattern in the subsoil.

\section{Ghana Soil Classification System}

In the system, the main determinants of soil formation in the forest zone are climate and vegetation. On the basis of these two factors, the soils studied in the HRF

Table 5: Classification of the soils into World Reference Base and Soil Taxonomy

\begin{tabular}{llll}
\hline Soil series & WRB (1998) & Soil Taxonomy (1998) & Ghanaian System \\
\hline $\begin{array}{l}\text { Soils in the HRF } \\
\text { Ninisu }\end{array}$ & Plinthic Ferralsol & \\
Ankasa & Plinthic Ferralsol & Plinthic Acrudox & Forest Oxysol \\
Boi & Plinthic Ferralsol & Plinthic Acrudox & Forest Oxysol \\
Bremang & Plinthic Ferralsol & Plinthic Acrudox & Forest Oxysol \\
& & Plinthic Acrudox & Forest Oxysol \\
Soils in the $\mathbf{M S D F}$ & & \\
Wacri & Rhodi-Lixix Ferralsol & & \\
Kukurantumi & Xanthic Ferralsol & Typic Eutrudox & Forest Oxysol \\
Bekwai & Ferri-Plinthic Acrisol (endoskeletic; & Typic Plinthustult & ForestOchrosolrhodic) \\
Nzima & Ferri-Plinthic Acrisol (endoskeletic) & Typic Plinthustult & Forest Ochrosol \\
Kokofu & Gleyi-Plinthic Acrisol & Typic Plinthustult & Forest Ochrosol \\
\hline
\end{tabular}


and MSDF keyed out as climatophytic earths. The criteria we used were low exchangeable bases, low CEC, low $\mathrm{pH}$ values and deep to very deep profiles. In this order, we differentiated two groups of soils as Forest Oxysols and Forest Ochrosols. The former group is dominant in the HRF and the latter in the MSDF. The system uses colour to distinguish between the two groups of soils at the Great Soil Group level.

1. Forest Ochrosols

On the basis of the criteria stated above, Bekwai, Nzima and Kokofu series were classified as Forest Ochrosols (Table 5). The characteristics colours ranged from red, reddish brown on the summits and upper slopes (Bekwai series) through brown on the middle slopes (Nzima series) to yellowish brown on the lower slopes (Kokofu series).

\section{Forest Oxysols}

Wacri and Kukurantumi series in the MSDF and all the profiles of the HRF were classified as Forest Oxysols (Table 5). These soils were distinguished from Forest Ochrosols by their very deep profiles, very low exchangeable bases and paler colours indicating higher rainfall regime. The differentiating colours used were orange brown to yellow rather than red or reddish brown for the Forest Ocsols.

\section{CONCLUSIONS}

The preliminary assessment of some key and easily measurable soil properties show that Oxisol (or Ferralsol) development is not limited to the HRF but also occurs in some parts of the MSDF, under udic moisture regimes.

Other conducive climatic variables like evapotranspiration being higher than rainfall in some parts of the year and rainfall exceeding the soil's water retention capacity at certain times in the year also promote Oxisol development in the two agro- ecological zones. The soils examined in the two zones are highly weathered, with the intensity being higher in the HRF than the MSDF. Soils in the HRF have lower silt:clay and CEC:clay values. The occurrence of Oxisols in the MSDF should, therefore, be taken into account in the management of soils, especially their pH levels (which give reflection of their basic cation levels) in the zone, where most of the upland soils are considered as Acrisols. Further detailed chemical, mineralogical and micromorphological studies are necessary to establish the pedogenetic changes and differences in soils studied in the two agro-ecological zones.

\section{REFERENCES}

Adu, S.V. and R.D. Asiamah (1992). Soils of the Ayensu-Densu Basin. Memoir No.9. Soil Research Institute, Kwadaso-Kumasi, Ghana.

Ahn, P.M. (1961). Soils of the Lower Tano Basin, South-Western Ghana. Memoir No.2. Soil Research Institute, Kwa daso-Kumasi, Ghana.

Andrede, H., Schaefer, C.E.R., Demante, J.L.I. and Andrade, F.V. (1997). Pedogeomorfologia e micropedologia de uma sequência Latossolo - Areira Quartzosa Hidromórfica do sobre rochas cristalinas do Estado do Amazona. Geonomos 5:55-66.

Asiamah, R.D. (1987). Ghana's soil resources and their agricultural utilization. In Proc. National Conference on Resource Conservation for Ghana's sustainable development. Vol.2, Kwame Nkrumah Conference Centre, Accra, Ghana 28 - 30 April, 1987.Vol.2 pp 99-111.

Barshad, I. (1965). Chemistry of soil development. In F.E. Bear (editor). Chemistry of the soil $2^{\text {nd }}$ Edition. Reinhold Publishing, New York. pp1 - 63. 
Bates, D. A. (1962) Geology. In Agriculture and Land Use in Ghana (editor) J. Brain Wills. Oxford University Press Oxford, UK.

Batjes, N.H. (1995). A global data set of soil $\mathrm{pH}$ properties. Technical Paper 27, ISRIC, Wageningen, Holland.

Batjes, N.H. (1996). A characterization of Ferralsols using the WISE database. .In J.H. Kaufmann (editor.) Proc. National Soil Reference Collections and Data base (NASREC). Vol.2. Wageningen, The Netherlands. Nov. 6-17, 1995.pp 45-61.

Beinroth, F.H., Uehara, G. and Ikawa, H. (1974). Geomorphic relationship of Oxisols and Ultisols on Kauai, Hawaii. Soil Sci. Soc. Am. Proc. 38: 128 -131 .

Beinroth, F.H., Eswaran, H., Uehara, G. and Reich, P. F. (2000). Oxisols. E373E392. In M.E. Summer (editor.) Handbook of Soil Science. CRC Press, London.

Beinroth, F.H. (1982). Some highly weathered soils of Puerto Rico. I. Morphology, formation and classification. Geoderma 27: 1-73.

Bouyoucous, G.J. (1962). Hydrometer method improved for making particle size analysis of soils. Agron. Jour: 54: $464-465$.

Brady, N. C. and Weil R. R. (1996). The Nature and Properties of Soils. PrinticeHall, Upper Saddle River, NJ, USA.

Brammer, H. (1962). Soils. In J.B. Wills (editor.) Agriculture and land use in Ghana. Oxford University Press. Oxford, UK. pp 88-126
Brash, H.T. (1962). Geomorphology. In J.B. Wills (editor.) Agriculture and land use in Ghana. Oxford University Press, Oxford, UK. pp 77-87.

Bray, R.H. and L.T. Kurtz (1945). Determination of total, organic and available forms of phosphorus in soils. Soil Science. 59: 39-45.

Bremner, J.M. (1965). Total nitrogen. In Black, C. A., Evans, D. D., White, J. L., Ensminger, L. E. and White, F. E. (editors.). Methods of Soil Analysis. Part 2, Chemical and microbiological properties.(2 ${ }^{\text {nd }}$ Edition). Agronomy 9; 199-223.

Brinkman, R. (1979). Ferrolysis, a soil - forming process in hydromorphic condi tions. Agric. Res. Rep. (Wageningen), Holland 887. Pudoc.

Carson, P.L. (1975). Recommended test for K. In recommended chemical soil test procedures for the North Central Region. North Dakota Agricultural Experimental Station. N.D. State University. Bulletin No. 499. pp 20-21.

Chadwick, O.A. and Graham, R. C. (2000). Pedogenic processes. In M.E. Summer (editor). Handbook of Soil Science. CRC Press London. E41-E72.

Charter, C.F. (1958). Interim Ghana Soil Classification. Department of Soil and Land Use Survey, Ghana.

Daniels, R.B., Gamble, E. E. and Cady, J. G. (1971). The relation between geomorphology and soil morphology and genesis. Advance. Agronomy. 23: 5188 .

FAO, (1990). Guidelines for soil description. $3^{\text {rd }}$ Edition (Revised). FAO, Rome. 
Eswaran, H.and Tavernier, R. (1980). Classification and genesis of Oxisols. In B.K. G. Theng (editor.) Soils with variable charge. New Zealand Soil Science. Society., Lower Hutt, New Zealand. pp427-442

Junner, N.R. (1940). Geology of the Gold Coast and Western Togoland. Gold Coast Geological Survey.

Lepsch, I.F. and Buol, S. W. (1974). Investigations in an Oxisol - Ultisol toposequence in Sao Paulo State, Brazil. Soil Sci. Soc. Am. Proc. 38: 491-496.

Lepsch, I.F., Buol, S. W. and Daniels, R. B. (1977). Soils - landscape relationship in the Occidental Plateau of Sao Paulo State, Brazil. Soil Sci. Soc. Am. J. 41: 109-115.

Lucas, Y., Chauvel, A., Boulet, R., Ranzani, G. and Scatolini, F. (1984). Transição Latossolos-Podzóis a formação Barreiras na região de Manaus, Amazônia. Rev. Bras. Cienc. Solo 8 (3): 325-336.

Mclean, E.O. (1982). Soil pH and lime requirement. In Page,A.L.,R.H. Miller and D.R. Keeney (Editor) Methods of soil analysis. Part 2 - chemical and microbiological properties $\left(2^{\text {nd }}\right.$ Edition). Agronomy 9;pp 199-223.

Miller, B.J. (1983). Ultisols. In L.P. Wilding, N.E. Smeck and G.F. Hall (editor.) Pedogenesis and Soil Taxonomy II. The Soil Orders. Elsevier Scientific, Amsterdam. The Netherlands. pp283323.

Nelson, D. W. and L. W. Sommers (1982) Total Carbon, Organic Carbon and Organic Matter. In: AL page, R.H. Miller and D. R. Keeney.(editor) Methods of Soil Analysis. 2. Chemical and Micro biological Properties. Agronomy 9:301 -312 .

Obeng, H. (1987). Soil management for sustainable agricultural production in Ghana. In proc. National Conference on Resource Conservation for Ghana's sustainable development. Kwame Nkrumah Conference Centre, Accra, Ghana. 28-30 April, 1987. Vol.2. pp 112-130.

Sanchez, P.A. and Boul, S.W. (1974). Properties of some soils of the Upper Ama zon Basin of Peru. Soil Sci. Soc. Amer. Proc. 38: 117-121

Sanchez, P.A. (1976). Properties and management of acid soils in the Tropics. John Wiley, New York.

Schaefer, C.E.R., Ker, J. C., Gilkes, R. G., Campos, J. C., da Costa L. M. and Saadi, A. (2002). Pedogenesis on the uplands of the Diamantina Plateau, Minas Gerais, Brazil: a chemical and micropedological study.

Singer, M.J. and Munns, D. N. (1987).Soil-An introduction. Macmillan, New York

Soil Survey Staff. (1995). Soil Survey Laboratory information manual. Soil survey investigation Report No. 45. Version 1.0. United

States Department of Agriculture. Natural Resources Conservation Service.

Soil Survey Staff. (1998). Keys to Soil Taxonomy. $8^{\text {th }}$ Edition. 1996. USDANARC. US Government Printing Office, Washington, DC.

Soil Survey Staff. (1999). Soil Taxonomy. $2^{\text {nd }}$ Edition. United States Department of Agriculture. Natural Resources Conservation Service. Agriculture Hand 
book No. 436.

Thomas, G.W. (1982). Exchangeable cations in Page, A.L.R.H. Miller, and D.R. Keeney(Editors), Methods of soil analysis , part 2 ; Chemical and Microbiological properties .Madison, WL; Soil Science Society of America, pp. 159-166.

Uexhull, H.R. Von and Mutert E. (1995). Global extent, development and economic impact of acid soils. Plant and Soil. 171 (1): 1-15.

Van Wambeke A. Eswaran, H.Herbillon AJ and Comerma J. (1983). Oxisols. In L.P. Wilding, N.E. Smeck and G.F. Hall ed). Pedogenesis and Soil Taxonomy II. The Soil Orders. Elsevier
Scientific Publishing co. Amsterdam. The Netherlands. pp 325-354

Van Wambeke, A (1992). Soils of the tropics: Properties and appraisal. McGraw Hill, New York.

Van Wambeke, A (1967). Recent development in the classification of soils of the Tropics. Soil Science. 104: 309-313.

Westin, F.C. and. de Brito, J. C. (1969). Phosphorus fractions of some Venezuelan soils as related to their state of weath ering. Soil Sci. 107: 194-202.

WRB (1998). World Reference Base for Soil Resources. World Resources Report No. 84. FAO, Rome. 